\title{
Pelatihan Perbaikan Perahu Kecil Fiberglass Reinforced Plastic (FRP) Untuk Budidaya Rumput Laut di Kabupaten Bantaeng
}

\author{
Wahyuddin Mustafa*, Syamsul Asri, Farianto Fachruddin L, Moh.Rizal Firmansyah, \\ Muh.Zubair Muis Alie dan Firman Husain \\ Departemen Teknik Perkapalan dan Kelautan, Fakultas Teknik UNHAS \\ wahyuddin.mustafa@unhas.ac.id*
}

\begin{abstract}
Abstrak
Penggunaan perahu berbahan FRP (fiberglass reinforced plastic), untuk keperluan budidaya rumput laut dan penangkapan ikan sudah banyak di gunakan oleh pebudidaya rumput laut dan nelayan di daerah pesisir. Perahu yang telah dioperasikan umumnya akan mengalami penurunan performa atau kegagalan fungsional terutama struktur lambung. Struktur lambung sangat rentan rusak baik saat pemakaian normal maupun akibat benturan dengan objek lain atau karena campuran bahan tidak sesuai dengan standar. Seperti halnya kasus yang terjadi pada komunitas nelayan dan pebudidaya rumput laut di Desa Bontosunggu Kecamatan Bisappu Kabupaten Bantaeng, beberapa perahu mengalami keretakan dan bocor hampir seluruh lambung perahu. Guna menjaga kelancaran produksi budidaya rumput laut tentu ketesediaan perahu harus tinggi salah satu cara menjaga ketersediaan adalah dengan melakukan pemeliharaan dan perbaikan.

Teknologi perbaikan perahu FRP sangat sederhana, tempat yang retak atau bocor terlebih dahulu di gerinda dan dibersihkan dan di lapisi ulang dengan bahan resin, mat, roving jika dibutuhkan warna maka ditambahkan bahan pigmen. Apabila memperhatikan standar bahan dan kerja mencakup pembersihan, komposisi campuran, pelapisan dan penyelesain akhir, niscaya hasil maksimal dapat diperoleh.

Pelatihan perbaikan perahu terbagi dalam tiga tahapan, melibatkan secara aktif anggota pebudidaya rumput laut yang berjumlah sekitar 12 (dua belas) orang. Tahap pertama dan kedua adalah penyampaian teori dan diskusi mencakup pengenalan bahan, peralatan, tata cara kerja dan K3 (keselamatan dan kesehatan kerja). Tahap ketiga adalah pembimbingan praktek perbaikan mencakup pembersihan badan perahu, pencampuran bahan, teknik-teknik laminasi dan penyelesain akhir.

Hasil yang diperoleh melalui diskusi dan praktek adalah (1) peserta memahami bahan yang standar digunakan untuk perbaikan FRP, yang sebelumnya banyak menggunakan bahan tambahan yaitu thinner padahal ini membuat bahan menjadi getas, mudah retak dan bocor. (2) peserta mampu mencampur bahan sesuai standar. (3) peserta mampu melaminasi perahu dengan susunan laminasi yang standar dan menerapkan teknik-teknik melapis dengan baik.

Simpulan yang dapat diperoleh setelah kegiatan terlaksana adalah peserta dapat memilih bahan yang tepat untuk perbaikan perahu oleh karena telah mengenali karakteristik bahan FRP secara baik dan dapat mengerjakan sendiri perbaikan perahunya sehingga dapat menghemat biaya produksi budidaya rumput laut serta tetap menjaga ketersediaan perahu sehingga proses produksi tetap lancar.
\end{abstract}

Kata Kunci: Perbaikan; Perahu; Fiberglass Reinforced Plastic; Resin; Mat; Roving; Pigmen.

\section{Pendahuluan}

Kabupaten Bantaeng adalah sebuah kabupaten di Provinsi Sulawesi Selatan Indonesia. Terletak di bagian selatan Provinsi Sulawesi Selatan. Memiliki luas wilayah 395,83 km2 atau 39,583 Ha yang dirinci berdasarkan lahan sawah mencapai $7.253 \mathrm{Ha} \mathrm{(18,32 \% )}$ dan lahan kering mencapai 32.330 Ha Secara administrasi Kabupaten Bantaeng terdiri atas 8 kecamatan yang terbagi atas 21 kelurahan dan 46 desa. Jumlah penduduk mencapai 190.000-an jiwa. Kabupaten Bantaeng terletak di daerah pantai yang memanjang pada bagian barat dan timur sepanjang 21,5 kilometer yang cukup potensial untuk perkembangan perikanan dan rumput laut. 
Usaha perikanan dan budidaya rumput laut di Bantaeng umumnya berskala usaha rakyat. Masyarakat pesisir Bantaeng melakukan usaha perikanan dan budidaya secara berkelompok maupun perseorangan. Salah satu kelompok atau komunitas pebudidaya rumput laut berada di Desa Bontosunggu Kecamatan Bisappu. Sarana produksi yang digunakan adalah peralatan budidaya dan perahu. Peralatan budidaya yang dimaksud adalah: tali, pelampung, pisau, dan tempat jemuran. Perahunya adalah perahu berukuran kecil atau yang biasanya disebut sampan yang terbuat dari FRP.

Perahu yang telah dioperasikan umumnya akan mengalami penurunan performa atau kegagalan fungsional terutama struktur lambung. Struktur lambung sangat rentan mengalami kerusakan atau patah atau retak saat pemakaian normal, akibat mengalami benturan dengan objek lain, kandas dan atau karena penggunaan bahan tidak sesuai dengan standar (West System, 2014;1). Seperti halnya kasus yang terjadi pada komunitas nelayan dan pebudidaya rumput di daerah ini beberapa perahu mengalami keretakan dan bocor hampir seluruh lambung perahu. Berdasarkan penyelidikan dengan memeriksa langsung kondisi perahu maka diperoleh beberapa temuan yaitu:

1. Kerusakan perahu umumnya karena benturan dan gesekan dengan benda lain saat proses menaikkan dan menurunkan perahu dari pantai ke laut.

2. Perahu-perahu yang mengalami kebocoran dan retak di reparasi sendiri akan tetapi tidak memperhatikan komposisi bahan yang standar, mereka menambahkan bahan yang tidak sesuai dalam proses pencampuran yaitu thinner dengan tujuan untuk menambah volume atau sebagai pengencer.

3. Tata cara laminasi tidak sesuai standar dan komposisi bahan dalam pencampuan tidak sesuai standar.

Melihat fenomena tesebut dan guna menjaga kelancaran produksi budidaya rumput laut lancar perlu dilakukan advokasi pemeliharaan dan perbaikan perahu kepada komunitas.

Advokasi yang dimaksud dan mendesak untuk dilakukan adalah pelatihan pemeliharaan dan perbaikan lambung perahu FRP terhadap komunitas, Hal ini yang mendorong Himpunan Mahasiswa Teknik Perkapalan dan Dosen-dosen Teknik Perkapalan Unhas melakukan kegiatan bernama Naval Dedicate, Enviromental, Care \& Knowledge yang selanjutnya di singkat NAVAL DECK, merupakan salah satu program yang dimaksudkan sebagai kegiatan Pengabdian Kepada Masyarakat (P2M) berupa kegiatan Bakti Sosial (pembersihan pesisir), Sosial (keselamatan maritim) dan Workshop (Perbaikan perahu fiberglass).

Target yang ingin dicapai melalui pelatihan ini adalah:

1. Mengenalkan material FRP sebagai bahan reparasi perahu.

2. Meningkatkan keterampilan kerja pemeliharaan di kalangan pengguna perahu fiberglass di Bantaeng.

Peningkatan keterampilan kerja pemeliharaan perahu FRP dimaksudkan untuk menjamin ketersediaan perahu sehingga akan menjaga proses produksi tetap berjalan lancar.

\section{Landasan Teori}

\subsection{Apa itu FRP?}

Fiberglass reinforced plastic (FRP) atau plastik diperkuat serat gelas, merupakan gabungan dari beberapa bahan (terutama serat gelas dan resin) membentuk lapisan-lapisan dan mengeras untuk 
membentuk laminasi yang solid. Jika disatukan dengan benar, laminasi dapat menjadi kuat dan kaku dengan ketahanan yang baik terhadap kelelahan dan pengaruh air. Jika dibangun buruk, laminasi mungkin masih terlihat baik di permukaan tetapi, karena kualitas yang buruk, dapat menurunkan setengah dari umur yang diharapkan atau bahkan kurang (Anmarkrud Thomas, 2009 p.1) dan (John McVeagh, et.all, 2010, pp.46-47).

\subsection{Bahan FRP}

\subsection{Minyak Resin (Epoxy Resin)}

Minyak resin bahan dasarnya terbuat dari minyak bumi dan residu tumbuhan. Adapun jenis resin yang umum digunakan untuk konstruksi perahu adalah jenis orthophthalic polyester resin. Untuk membuat campuran menjadi keras maka digunakan cairan kimia (hardener) yang biasa disebut dengan Katalis (catalis), seperti terlihat pada Gambar 1.

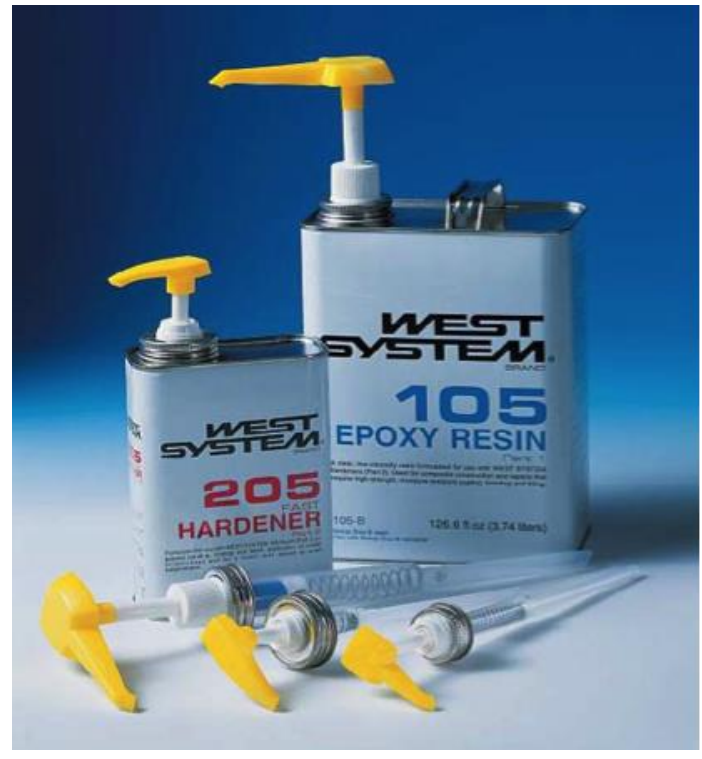

Gambar 1. Minyak Resin dan Katalis

Sumber: Marshall Roger (2010)

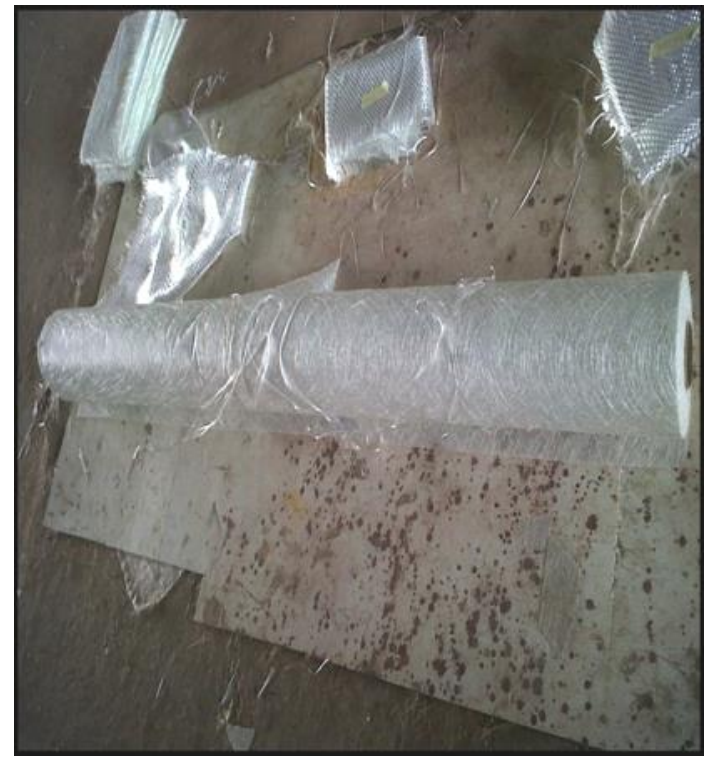

Gambar 2. Contoh Mat

Sumber: Anmarkrud Thomas (2010)

\subsection{Chopped Strand Mat (CSM) atau serat halus}

Terbuat dari bahan polyester, sebagi media lapisan permukaan sebuah plat fiber, seperti terlihat pada Gambar 2.

\subsection{Waven Roving (WR) atau serat kasar}

Terbuat dari bahan polyester/epoxy, digunakan sebagi media lapisan tengah dari plat fiberglass. Serat penguat merupakan serat gelas yang memiliki kekakuan dan kekuatan tarik yang tinggi serta modulus elastisitas yang cukup tinggi, seperti terlihat pada Gambar 3. 


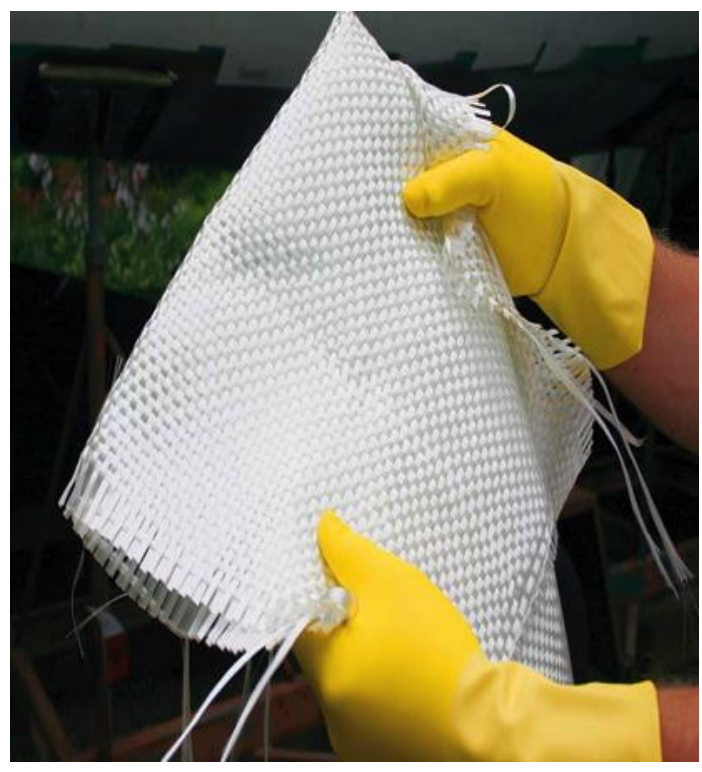

Gambar 3. Roving

Sumber: Marshall Roger (2010)

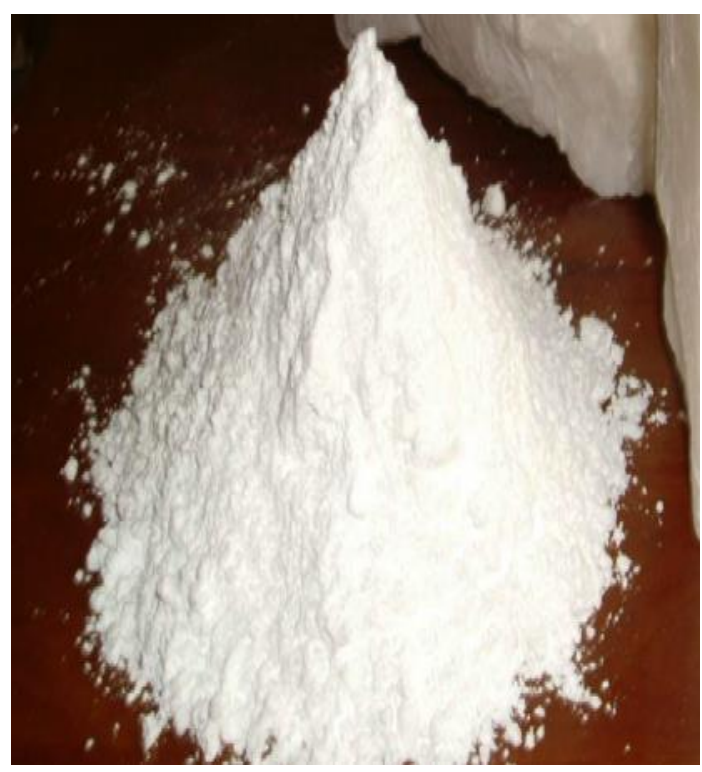

Gambar 4. Talc (Tepung Khusus)

Sumber: Anmarkrud Thomas (2010)

\subsection{Talc (tepung khusus)}

Digunakan untuk membuat lemfiber (jackcoat) serta untuk membuat campuran cat plincoat, seperti terlihat pada Gambar 4.

\subsection{Pigmen (pewarna)}

Digunakan untuk memberi warna pada resin dan talc, warna tersedia bermacam-macam, seperti terlihat pada Gambar 5.

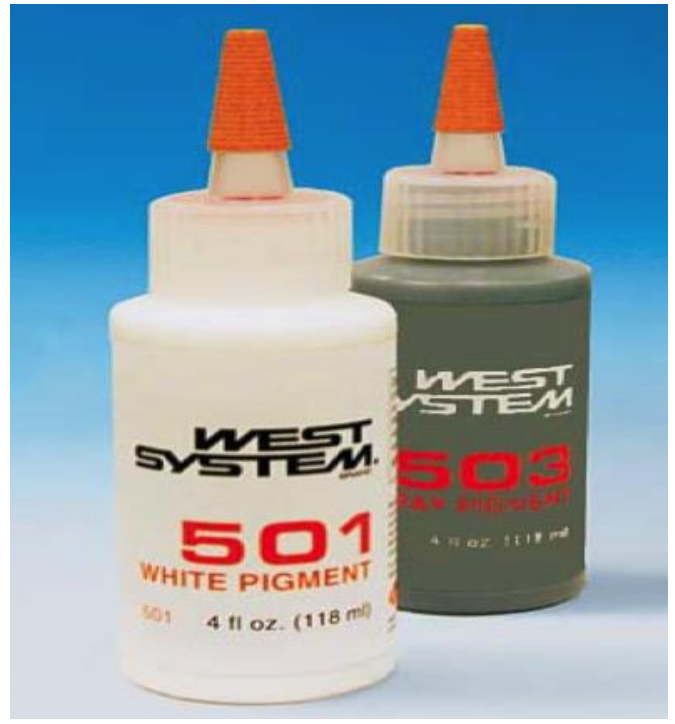

\section{Gambar 5. Pigmen}

Sumber: Marshall Roger (2010) 


\subsection{Alat dan Perlengkapan}

Kuas paling cocok untuk penggunaan untuk gelcoat dan resin polyester terutama pada daerah sudut sempit dan detail-detail kecil. Kuas rol dari berbagai ukuran dapat digunakan. Rol harus terbuat dari bahan yang tidak akan rusak oleh pelarut, seperti terlihat pada Gambar 6.a. Gerinda poles dan potong, digunakan saat lambung perahu didempul, diperhalus permukaannya dan memotong FRP, seperti terlihat pada Gambar 6.b.

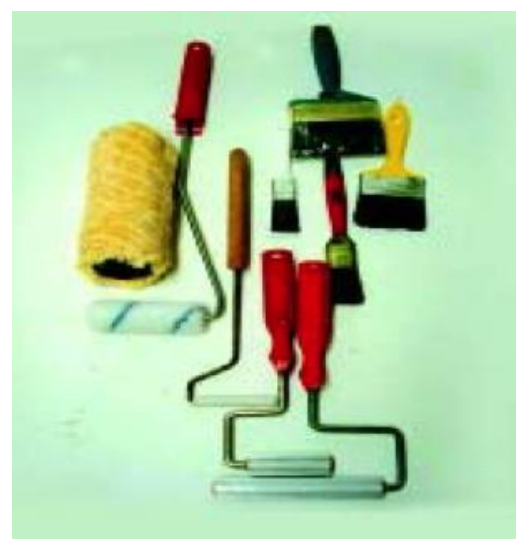

a

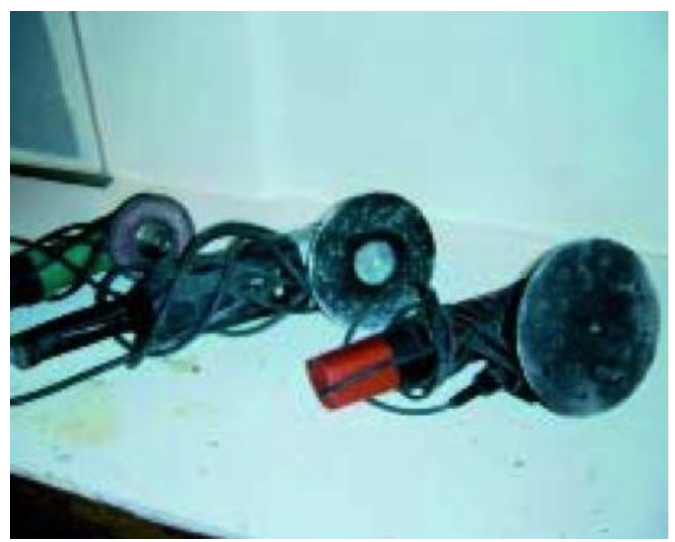

$\mathrm{b}$

Gambar 6. Peralatan Kerja (a) Kuas Sapu dan Kuas rol; (b) Gerinda

\subsection{Penanganan bahan FRP}

Bahan FRP harus dilindungi dari sinar matahari langsung, angin dan hujan, seperti terlihat dalam ilustrasi Gambar 7.a. Pada iklim tropis, bahan FRP harus disimpan dalam kondisi gelap dan dingin mungkin untuk memastikan bahan tidak rusak (shelf-life) atau simpan di tempat kering, seperti terlihat pada Gambar 7.b.

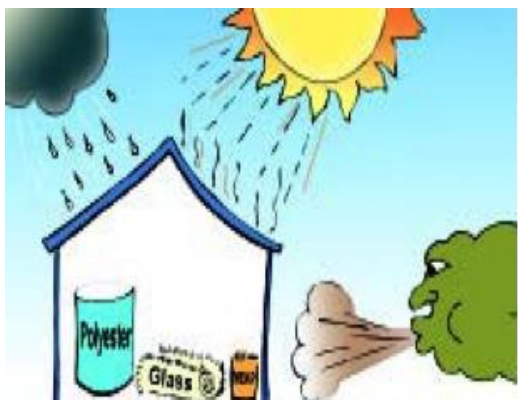

a

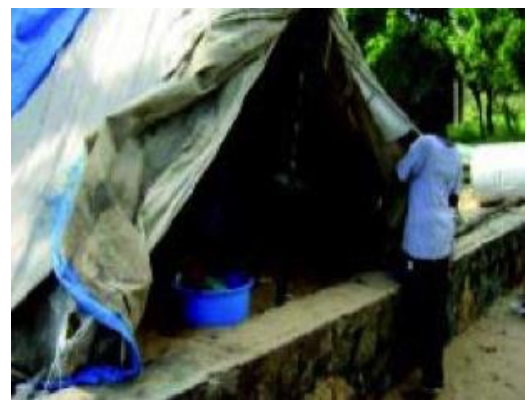

b

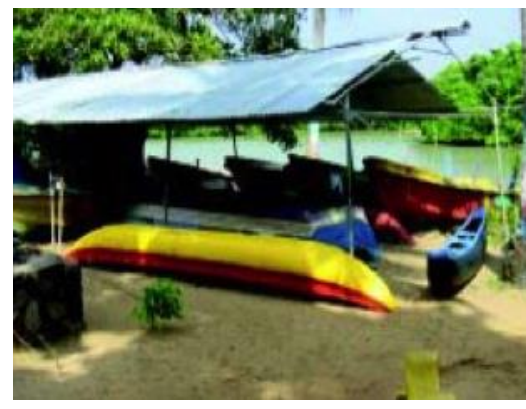

C

Gambar 7. Penanganan Bahan (a) Pelindungan terhadap Matahari, Angin dan Hujan;

(b) Penyimpanan Bahan di Tempat Kering; (c) Tempat Penampungan Perahu Sumber: Anmarkrud Thomas, et.all (2010) 
Hal ini sangat penting untuk melindungi area kerja dari matahari, angin dan hujan. Jika tempat penampungan seperti yang ditunjukkan pada Gambar 7.c tidak mungkin, penampungan sementara harus dibangun, misalnya menggunakan terpal.

Beberapa hal yang dapat dilakukan dalam pekerjaan perbaikan FRP.

1. Selalu periksa bahwa pemasok memberikan bahan FRP yang sesuai.

2. Jaga agar FRP kering dan bersih.

3. Semua bahan yang berhubungan dengan polyester harus disimpan di tempat gelap dan sejuk mungkin, dan pengeras harus disimpan secara terpisah.

4. Pastikan gelcoat itu dan resin telah dicampur dengan baik dalam drum atau wadah sebelum digunakan, untuk menghindari aditif menetap di bagian bawah.

5. Idealnya, saat melakukan pekerjaan perbaikan, semua bahan baku, perahu itu sendiri dan lingkungan harus pada suhu yang sama.

\subsection{Perbaikan Kerusakan Laminasi}

\subsection{Penandaan dan Pembersihan}

Menandai (marking) daerah pada permukaan laminasi yang akan dihaluskan /digerinda, seperti terlihat pada Gambar 8.a. Sebelum di gerinda, semua kotoran permukaan, seperti minyak dan silikon, harus dicuci bersih dan dihapus dengan pelarut yang sesuai. seperti terlihat pada Gambar 8.b. Permukaan harus dihaluskan dengan kertas amplas, baik secara manual atau dengan alat-alat listrik, seperti mata gerinda, seperti terlihat pada Gambar 8.c.

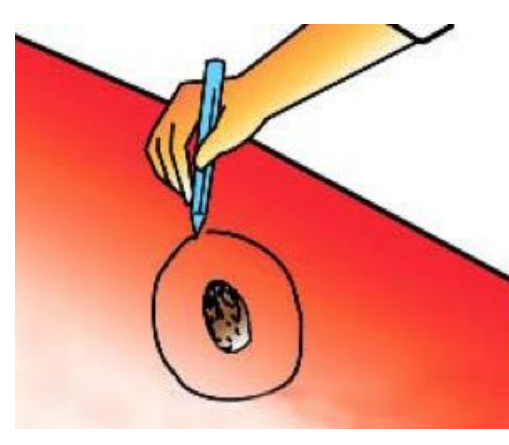

a

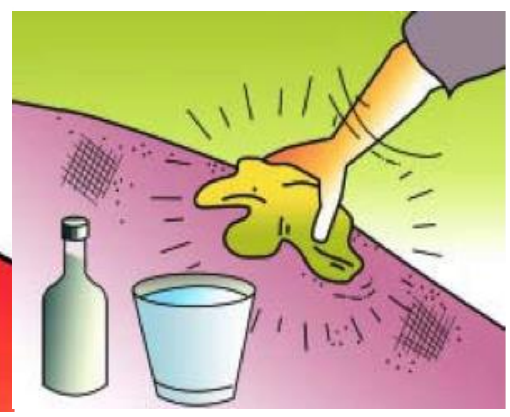

b

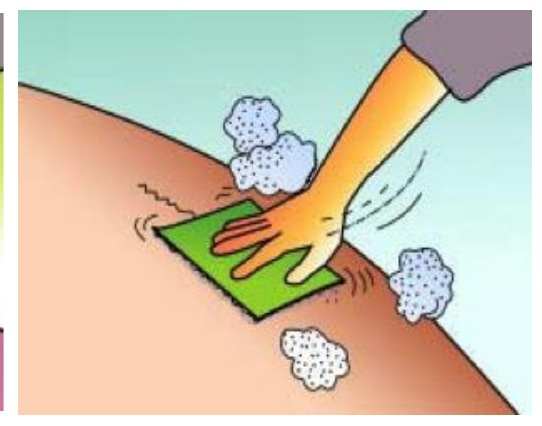

C

Gambar 8. Penandaan dan Pembersihan (a) Penandaan yang Rusak;

(b) Pembersihan sebelum Penandaan; (c) Pembersihan dengan Amplas dan Gerinda. Sumber: Anmarkrud Thomas,et.all (2010) 


\subsection{Pemotongan Mat}

Untuk pekerjaan perbaikan sederhana, pemotongan mat (CSM), harus disesuaikan dengan luas permukaan yang akan diperbaiki. Potongan pertama harus sesuai dengan luas lubang. Ukuran potongan berikutnya harus meningkat secara bertahap.

\subsection{Campuran Resin dan Katalis}

Resin dan pengeras harus dicampur. Jumlah katalis (hardener) adalah sebanyak $5 \mathrm{ml}(0,18 \mathrm{oz})$ untuk setiap $500 \mathrm{ml}(17,6 \mathrm{oz})$ dari resin. Sebuah botol plastik dapat digunakan untuk mengukur resin. Ini harus berisi persis 500ml (17,6 oz), seperti terlihat pada Gambar 9.a. Resin dituangkan ke dalam ember Jumlah katalis yang benar untuk dicampurkan dengan resin adalah 1 persen, namun 0,8 persen akan normal juga bekerja di daerah tropis, seperti terlihat pada Gambar 9.b.

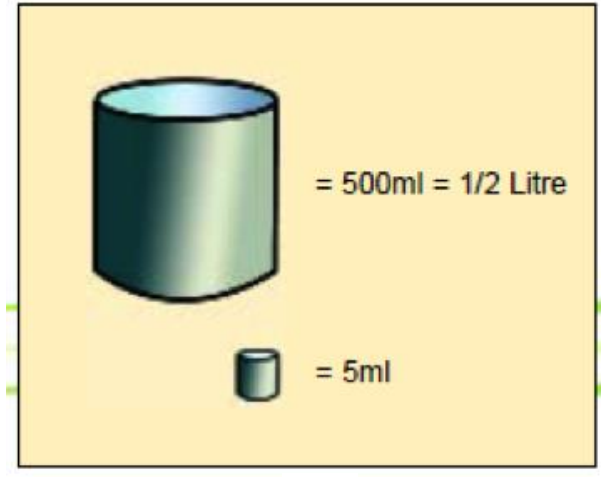

a

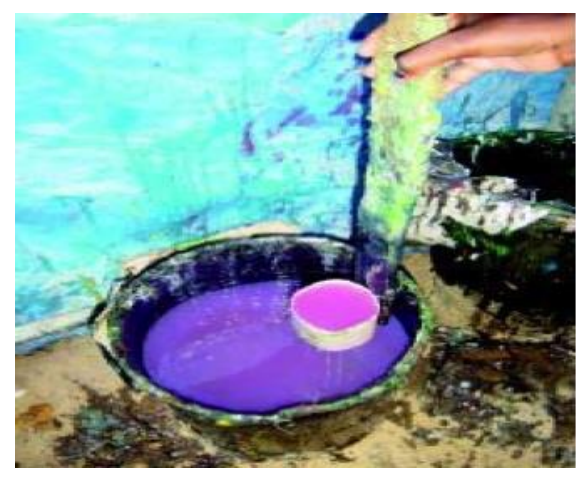

$\mathrm{b}$

Gambar 9. Campuran Resin dan Katalis (a) Rasio Resin dan Katalis;

(b) Pencampuran dalam Ember

Sumber: Anmarkrud Thomas,et.all (2010)

Jumlah kebutuhan resin polyester untuk fiberglass. Misalnya, jumlah resin untuk 1,0 $\mathrm{m}^{2}$ dari $450 \mathrm{~g} / \mathrm{m}^{2} \mathrm{CSM}$ adalah $1000 \mathrm{~g}$ (atau $1 \mathrm{~kg}$ ), seperti terlihat pada Gambar 10.

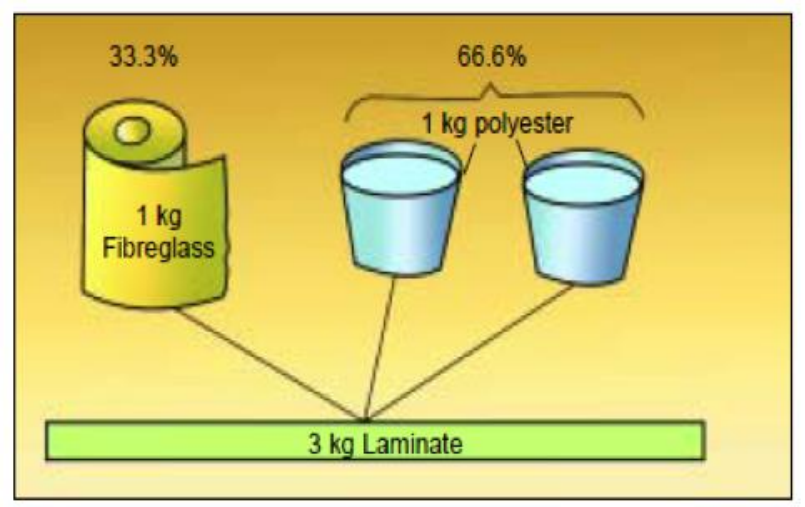

Gambar 10. Rasio Kebutuhan Resin dengan Mat dan Roving

Sumber: Anmarkrud Thomas,et.all (2010) 


\subsection{Pelapisan/Laminasi}

Selalu melapiskan resin terlebih dahulu sebelum menggunakan mat fiberglass, seperti terlihat pada Gambar 11.a. Lapisan resin berikutnya di aplikasikan setelah menggunakan serat gelas, seperti terlihat pada Gambar 11.b. Gunakan kuas rol guna mengurangi gelembung udara dan memadukan lapisan resin dan mat serat gelas, seperti terlihat pada Gambar 11.c.

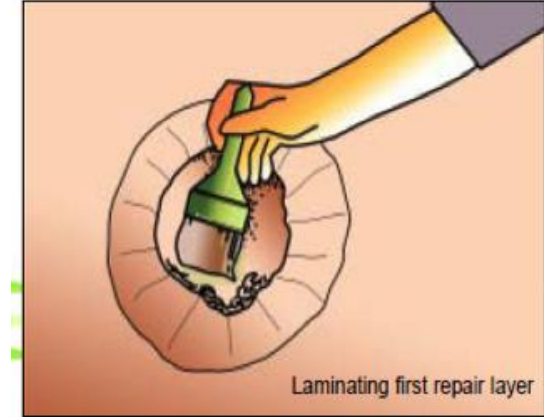

a

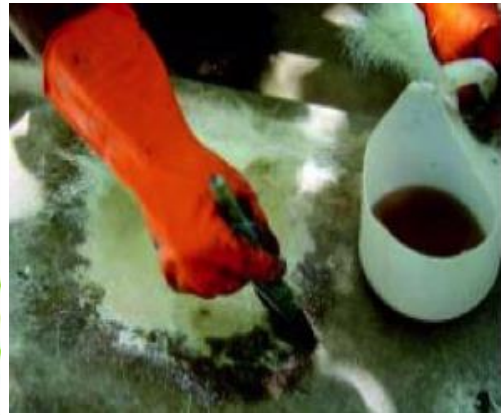

b

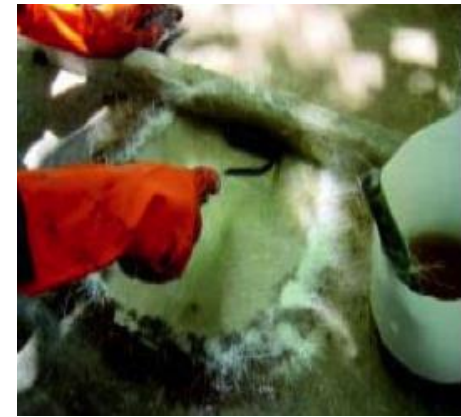

C

Gambar 11. Laminasi (a) Pelapisan Resin; (b) Pelapisan Mat dan Roving; (c) Memadukan Lapisan Resin, Mat dan Roving Sumber: Anmarkrud Thomas, et.all (2010)

\subsection{Kesehatan dan Keselamatan Kerja (K3)}

Pekerjaan dengan bahan FRP merupakan pekerjaan yang berisiko terhadap keselamatan dan kesehatan, oleh karena itu selalu gunakan pelindung mata/kaca mata (eye protection), jika akan mengerjakan FRP oleh karena merupakan bahan kimia berbahaya, yang dapat menyebabkan iritasi mata dan kerusakan mata lainnya. Selalu gunakan masker (respirator and/or dust mask) guna melindungi diri dari bahaya gas dan debu FRP akibat pengamplasan/pengerindaan. Selalu gunakan kaos tangan (gloves) guna melindungi kulit dari bahaya cairan kimia, seperti terlihat pada Gambar 12.
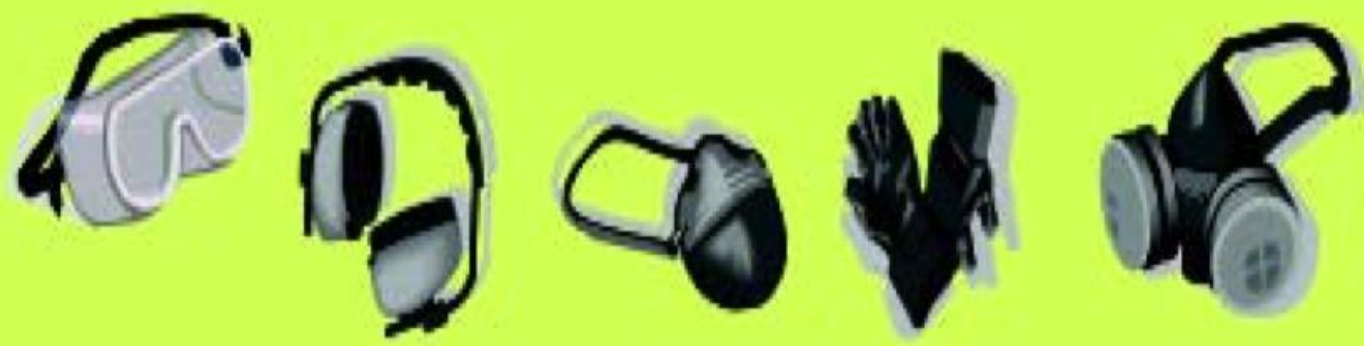

Gambar. 12 Perlengkapan K3

Sumber: Anmarkrud Thomas,et.all (2010) 


\section{Metode}

Berdasarkan permasalahan yang dperoleh sebagaimana dijelaskan pada pendahuluan maka solusi yang ditawarkan berupa pelatihan dan pembimbingan kepada pebudidaya dan nelayan, dengan tahapan sebagai berikut:

1. Tahap pertama; Penyuluhan kepada pebudidaya dan nelayan terkait $F R P$ secara interaktif, dilakukan tanyajawab, terkait pengenalan $F R P$ apa dan bagaimana itu $F R P$, dan metode perbaikan perahu $F R P$, baik perbaikan dengan skala kecil maupun perbaikan skala besar.perbaikan skala kecil meliputi, pengikisan kulit, keretakan kulit dan konstruksi. Perbaikan skala besar ini diantaranya, terjadi kebocoran pada perahu, perahu patah akibat tubrukan maupun akibat ketidaksempurnaan konstruksi.

2. Tahap kedua; mengenalkan, melatih dan membimbing pebudidaya dan nelayan mengenai penggunaan peralatan atau perlengkapan yang digunakan dalam pemeliharaan dan perbaikan lambung perahu FRP, termasuk peralatan keselamatan dan kesehatan kerja. Kemudian dilakukan pembimbingan proses perawatan dan perbaikan lambung perahu mulai pencampuran resin dan katalis, pelapisan mat, pelapisan rovin, pewarnaan dan finishing.

3. Tahap ketiga; melakukan pendampingan pada praktek perbaikan perahu yang rusak, diikuti oleh pebudidaya dan nelayan sebanyak 12 (dua belas) orang. Tiap peserta mengambil peran serta dalam proses perbaikan perahu, dimulai dari pembersihan perahu, penandaan bagian perahu yang rusak, pelapisan matt, roofing, hingga proses pewarnaan sampai kepada finishing.

Semua tahapan ini dilaksanakan pada sebuah tempat di Desa Bontosunggu Kecamatan Bisappu Kabupaten Bantaeng yang melibatkan Dosen Teknik Perkapalan Unhas sebagai narasumber, mahasiswa teknik perkapalan sebagai panitia pelaksana Naval Deck dan komunitas pebudidaya dan nelayan.

\section{Hasil dan Diskusi}

Program Naval Deck mencakup pelatihan perbaikan perahu, agar mencapai target dilakukan beberapa tahapan yaitu:

Pertama: Penyusunan buku panduan sebagai media atau sarana penyampaian informasi ke peserta pelatihan. Buku panduan dibuat sederhana dan interaktif berisi contoh-contoh kerusakan yang umum terjadi di perahu FRP baik yang skala kecil maupun besar, terminologi FRP (Fiberglass reinforced plastic atau Plastik diperkuat Serat Gelas), Bahan FRP, metode perbaikan, penanganan dan penyimpanan bahan, kesehatan dan keselamatan kerja (K3) dan lingkungan.

Kedua; mengidentifikasi kebutuhan material langsung dan tidak langsung mencakup kebutuhan resin, hardener, mat, roving, talk, pigmen, mata gerinda, amplas, sabun colek, mesin gerinda, gunting dan lain - lain dengan panitia Naval Deck.

Ketiga; pekerjaan persiapan adalah memastikan tempat pelaksanaan pelatihan dan bimbingan memenuhi syarat-syarat minimum untuk pekerjaan FRP seperti terlindungi dari matahari langsung, hujan dan angin dengan melibatkan panitia Naval Deck dan pebudidaya. 
Pelaksanaan pelatihan diawali dengan menyampaikan teori tentang FRP mencakup bahan FRP, penyimpanan dan penanganan bahan FRP, metode reparasi, K3 dan lingkungan. Dilanjutkan dengan tanya jawab antara nara sumber dan peserta.

Atensi peserta sangat baik dengan kehadiran sesuai target yaitu sebanyak 12 (dua belas) orang dan pertanyaan-pertanyaan yang diajukan lugas dan dalam. Suasana pelatihan berubah menjadi ajang diskusi yang mempertemukan pengalaman-pengalaman peserta dengan teori-teori terkini tentang FRP yang digunakan pada perahu. Visualisasi kegiatan penyampaian teori seperti terlihat pada Gambar 13.a.

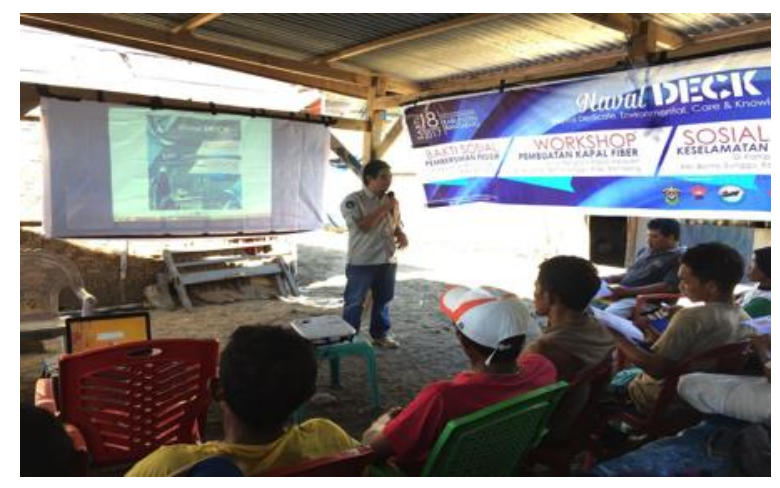

a

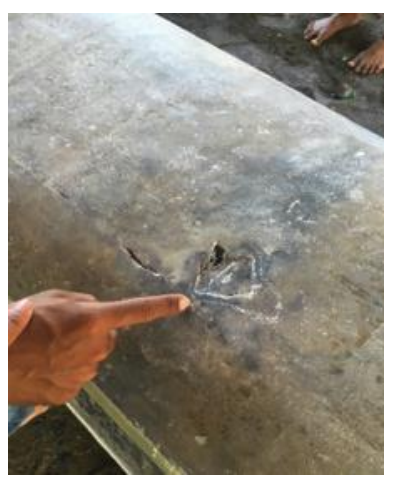

b

Gambar 13. (a) Penyajian Teori dan Diskusi; (b) Pemerikasaan Kondisi Perahu Sumber: Naval Deck (2017)

Tahap berikutnya adalah memperagakan penggunaan alat kerja mencakup penggunaan mesin gerinda untuk memotong dan menghaluskan, alat keselamatan mencakup pelindung mulut (masker), pelindung mata (kacamata) dan pelindung tangan (kaos tangan), dilanjutkan demonstrasi cara mencampur resin dan hardener yaitu dengan perbandingan 1: 100 artinya untuk setiap $5 \mathrm{ml}(0,18 \mathrm{oz})$ di campur $500 \mathrm{ml}(17,6 \mathrm{oz})$ resin, seperti ilustrasi pada Gambar 9.

Tahapan berikutnya berupa peragaan pelapisan matt, roving secara bergantian. Kebutuhan jumlah resin polyester untuk fiberglass dapat ditentukan misalnya, jumlah resin untuk $1,0 \mathrm{~m}^{2}$ dari $450 \mathrm{~g} / \mathrm{m}^{2} \mathrm{CSM}$ adalah $1000 \mathrm{~g}$ (atau $1 \mathrm{~kg}$ ), seperti ilustrasi pada Gambar 10 dan 11.

Pada kegiatan ini, perahu yang diperbaiki hanya (1) satu, berdasarkan pemeriksaan secara detail kondisi perahu didapatkan kerusakan skala besar dan kecil yaitu perahu bocor di haluan, tengah dan buritan. Tebal kulit sisi dan lambung berkisar 3 (tiga) mm saja tidak sesuai dengan standar BKI yaitu sekitar $4 \mathrm{~mm}$, untuk panjang perahu 6-7 meter.

Solusi dalam penanganan atau reparasi perahu yaitu :

1. Mengeringkan perahu.

2. Membersihkan seluruh permukaan perahu baik di dalam maupun diluar dari kotoran-kotoran yang menempel menggunakan amplas dan mata gerinda, seperti terlihat pada Gambar 13.b.

3. Menandai daerah - daerah yang rusak. 
4. Dilakukan pemotongan lambung perahu atau pada daerah yang mengalami kebocoran dan retak.

5. Memotong-motong mat dan roving sesuai dengan luas potongan dan melebihkan sebesar 2 cm untuk lapisan berikut.

6. Mencampur resin dan katalis dan melapiskan resin terlebih dahulu kepada daerah yang bocor dan retak.

7. Menempel potongan mat sampai tertutupi bocoran dan retakan.

8. Setelah kering sentuh, dilakukan pelapisan keseluruh badan kapal yang telah ditandai dengan menggunakan isolasi.

9. Pelapisan dilakukan untuk menambah ketebalan kulit yang tidak memenuhi standar BKI dilakukan dari dalam lambung sekalian melapisi patahan. Lapisan pertama dilakukan dengan memberikan resin secara merata kemudian dipasangkan matt 300, setelah itu di berikan resin lagi secara merata kemudian dipasangkan roving 600 sebagai lapisan kedua, dan lapisan matt 300 untuk lapisan ketiga, seperti terlihat pada Gambar 14.a.

10. Penyelesaian akhir berupa pemberian warna dengan cara mencampurkan resin dengan talc dan pigmen wana biru, kemudian di lapiskan keseluruh lambung kapal yang telah di tandai, seperti terlihat pada Gambar 14.b.

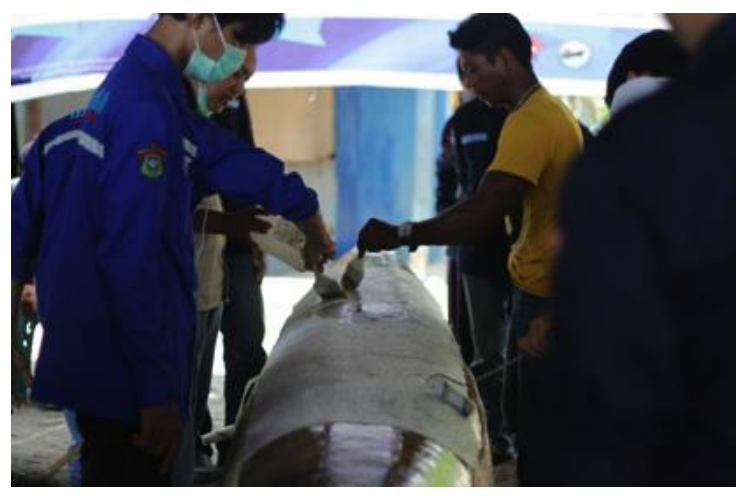

a

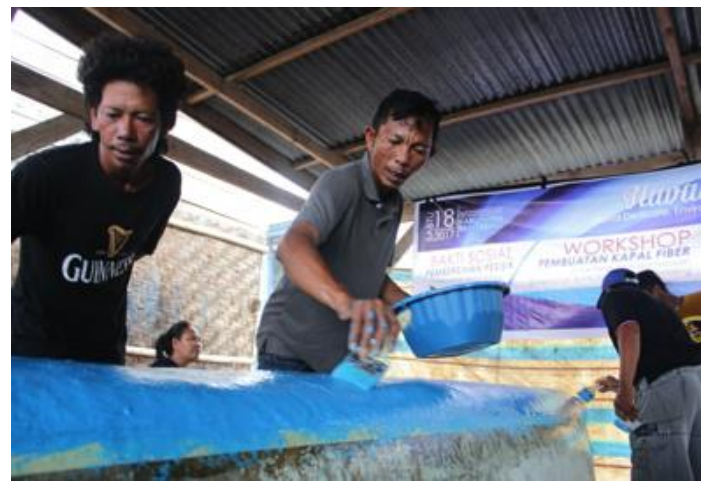

b

Gambar 14. (a) Pelapisan Resin, Mat dan Roving; (b) Pelapisan Resin, Talc dan Pigmen Sumber: Naval Deck (2017)

Setelah dilakukan pelatihan dan bimbingan kepada komunitas pebudidaya dan nelayan tentang reparasi perahu maka hasil yang kelihatan nyata adalah:

1. Peserta mampu membedakan karakteristik masing - masing bahan FRP.

2. Peserta mampu menggunakan alat dalam proses pekerjaan reparasi, terutama alat pertukangan dan alat - alat keselamatan.

3. Peserta mampu mencampur resin dan hardener sesuai standar pabrikan.

4. Peserta mampu melakukan pelapisan menggunakan resin, mat dan roving.

5. Peserta mampu melakukan pelapisan menggunakan campuran resin, talc dan pigmen.

Beberapa hal yang menjadi topik diskusi pada pelatihan yaitu:

1. Bahan. 
Sebelum pelatihan ini hampir semua peserta menambahkan thinner dalam campuran resin dan hardener dalam melakukan pekerjaan FRP. Mereka mendapatkan informasi yang salah yakni bahwa sama dengan aplikasi cat, thinner dapat menambahkan volume dan karena alasan harga resin relatif mahal. Hal ini tidak dianjurkan dan di larang oleh pabrikan karena dapat berdampak pada kekuatan tarik bahan.

2. Teknik pelapisan.

Sebelum pelatihan ketika mengerjakan pelapisan kepada daerah yang bocor mereka tidak mengeringkan, membersihkan dan menggurinda bagian yang akan di lapisi sehingga tidak terjadi senyawa yang baik dengan lapisan berikutnya yang mengakibatkan tidak menyatunya bahan, ini terlihat dari potongan-potongan lapisan yang dibongkar saat pembersihan ada lumut yang menempel, berarti ada air yang terperangkap disela-sela lapisan yang tidak menyatu.

\section{Kesimpulan}

Kesimpulan yang dapat diperoleh setelah kegiatan terlaksana adalah peserta dapat memilih bahan yang tepat untuk perbaikan perahu oleh karena telah mengenali karakteristik bahan FRP secara baik dan dapat mengerjakan sendiri perbaikan perahunya sehingga dapat menghemat biaya produksi budidaya rumput laut serta tetap menjaga ketersediaan perahu sehingga proses produksi tetap lancar.

\section{Ucapan Terima kasih}

Terima kasih kepada semua pihak yang mendukung terlaksanya kegiatan ini yaitu Ketua Himpunan Mahasisma Depatemen Teknik Perkapalan Unhas Muhammad Ilham, Ketua Panitia Naval Deck Dwiki Timur Pratama Bakri serta seluruh rekan-rekannya dan komunitas pebudidaya dan nelayan di Desa Bontosunggu Kecamatan Bisappu Kabupaten Bantaeng.

\section{Daftar Pustaka}

Anmarkrud T. (2009). Fishing Boat Construction: 4, Building an Undecked Fibreglass Reinforced Plastic Boat, FAO, Rome, Italy.

Anmarkrud Thomas, et al. (2010). Guide to Simple Repairs of FRP Boats in a Tropical Climate. FAO, Rome, Italy.

BKI, (1996). Rules and Regulations for the Classification and Construction of Ships, FRP Ships, Biro Klasifikasi Indonesia, Jakarta.

McVeagh, J., Anmarkrud, T., Gulbrandsen, O., Ravikumar, R., Danielsson, P., Gudmundsson, A. (2010). Training Manual on The Construction of FRP Beach Landing Boats. FAO, Rome, Italy.

Marshall Roger. (2010). Fiberglass Boat Repairs Illustrated, International Marine / MC-GrawHill, New York, USA.

West System. (2014). Fiberglass Boat Repair \& Maintenance, Gougeon Brothers, Inc., Bay City, MI USA, pp. 002-550. 